\author{
Prof. dr. sc. Petar Bačić, \\ Redoviti profesor Ustavnog prava, Pravni fakultet Sveučilišta u Splitu
}

\title{
CORONA ANTE PORTAS I "USTAV IZVANREDNOG STANJA" U AKTUALNOJ POLITICI I PRAVU SPORTA
}

\author{
UDK: 616.2-036.21 : 342.4 \\ 616.2-036.21: 796 \\ DOI: $10.31141 / z r p f s .2021 .58 .139 .105$ \\ Izvorni znanstveni rad \\ Primljeno: 20. listopada 2020.
}

\begin{abstract}
Sportski sektor je samo jedno u nizu područja teško pogođenih pandemijom Covid-19 i mjerama koje su državne vlasti širom svijeta poduzele protiv širenja smrtonosnog virusa. Odgode i otkazivanja većine sportskih natjecanja, počevši od Olimpijskih igara u Tokiju 2020. preko niza drugih događaja međunarodnog, nacionalnog i lokalnog značaja, još su jednom ukazale na nezamjenjivu ulogu i značaj koordinirane akcije politike i prava na svim razinama. Ova nam je situacija ponovno otkrila važnost ustava izvanrednog stanja (emergency constitution) u javnom pravu, ali i drugih pravnih klauzula (force majeure) s kojima će se konfrontirati sportske federacije, organizatori natjecanja, klubovi i sami sudionici u nastojanju razrješenja ozbiljnih ekonomskih i financijskih izazova te posljedica glede pravnih obveza koje su nastale ugovorima na području sponzorstva, prodaje i prijenosa sportskih događaja, itd. U ovom tekstu autor ukazuje na postojanje ustava izvanrednog stanja, njegove oblike i primjere u komparativnom ustavnom pravu, kao i na karakter događaja koji su tijekom 2020. godine pratili nastanak i djelovanje institucija u pokušaju zaštite društva. Pritom je jedno od temeljnih pitanja i je li Republika Hrvatska koristeći de iure ili de facto izvanredno stanje pomogla ili odmogla sportu.
\end{abstract}

Ključne riječi: ustav izvanrednog stanja, razlozi proglašavanja izvanrednog stanja, sport, komparativno ustavno pravo, Republika Hrvatska

"... na pravo najpogubnije djeluje ona doktrina... prema kojoj se svaka njegova odredba može suspendirati u vrijeme bilo kojih hitnih okolnosti koje zadese državu."

Ex parteMilligan, 71 U.S. (4 Wall.) 2 (1866)

\section{UVODNA NAPOMENA}

Svijet je u 2020. godini na dramatičan način obilježila pandemija uslijed širenja novog, do sada nepoznatog i smrtonosnog koronavirusa koji uzrokuje infektivnu 
bolest COVID-19. ${ }^{1} \mathrm{U}$ munjevitom i agresivnom ekspanzionističkom pohodu virus je prisilio javne vlasti velikog broja država na deklaraciju, organizaciju i realizaciju niza novih, diferenciranih, redom strogih mjera zaštite društva i njegovih članova. Ovo je dakako situacija koja još traje i čije posljedice još ni izbliza nisu definitivno sumirane. Ona je pritom šokiranoj i istraumatiziranoj nacionalnoj, europskoj i međunarodnoj javnosti ponovno otkrila postojanje "ustava izvanrednog stanja" (emergency constitution, costituzione di emergenza, constitution d'urgence), a s njim i niz kontroverzi glede njegovog de iure odnosno de facto karaktera i posljedica. Riječ je najozbiljnijim mogućim pitanjima s kojima se društvo suočava, a to nam jasno pokazuje aktualno stanje komparativne državnopravne teorije i prakse širom svijeta obilježenog pandemijom.

Pošast korona virusa kao da je otvorila Pandorinu kutiju, iz koje su zatim nahrupila sva moguća pitanja - počevši od onih neposredno medicinsko-zdravstvenih o prirodi virusa, njegovim izvorima i slabostima, o proizvodnji cjepiva i organizaciji masovnog cijepljenja stanovništva, sve do drugih širih i općih društvenopolitičkih pitanja, primjerice o tome hoće li zazivanje de facto ili de iure izvanrednog stanja zbog pandemije ponovno staviti na kušnju sposobnosti demokratskog uređenja da se nosi s izazovima krize važnih segmenata državne i društvene organizacije. U tom skupu pitanja posebno su se istaknula i ona sportskog karaktera, jer sport je volensnolens jedan od najvažnijih segmenata društvenog života suvremenog građanina. Tako je primjerice pitanje otkazivanja globalnih manifestacija poput Olimpijskih igara, kao i drugih velikih i prestižnih, ali i malih odnosno lokalnih sportskih natjecanja u značajnom broju i to ne samo najpopularnijih sportova (nogometu, košarci, atletici, itd.), otvorilo složene probleme javnog i privatnog prava čije se posljedice još saniraju. ${ }^{2}$

U tekstu ukratko ukazujemo na pojam ustava izvanrednog stanja u komparativnom ustavnom pravu, na dvojbe povezane s njegovim proglašavanjem, ovlastima koje se posljedično aktiviraju, ciljeve koje se mjerama donesenima na temelju tih ovlasti nastoji postići, te se posebno osvrćemo na političke i pravne reakcije velikih sportskih saveza u odnosu na Covid-19 pandemiju. Izvanredna stanja uvijek prati

\footnotetext{
"Koronavirusi su velika porodica virusa, koje nalazimo kod ljudi i životinja. Pod elektronskim mikroskopom ovi virusi imaju oblik krune, zbog čega su nazvani po latinskoj riječi corona, što znači 'kruna'. Neki koronavirusi poznati su od 1960-ih godina kao uzročnici bolesti kod ljudi, od obične prehlade do težih upala dišnog sustava. No, od 2003. g. počeli su se pojavljivati novi koronavirusi, koji su sa životinja prešli na ljude te se počeli širiti s čovjeka na čovjeka. Dakle, nakon pojave SARS-a u Kini 2002. g. te MERS-a na Bliskom istoku 2012. g. (koji se još uvijek pojavljuje), sada ponovno imamo novi koronavirus koji se pojavio u Kini. (...) Novi koronavirus je novi soj koronavirusa koji do sada nije bio otkriven kod ljudi. Svjetska zdravstvena organizacija ga je nazvala SARS-CoV-2 (SARS-coronavirus-2), a bolest koju uzrokuje COVID-19 (coronavirus disease). Otkriven je u Kini krajem 2019. godine." Usp. "Novi koronavirus i bolest koju uzrokuje COVID-19", https://www.zzjzdnz.hr/hr /zdravlje/prevencijazaraznih-bolesti/1369

2 Opširnije vidi Legal Responses to Health Emergencies: Argentina, Australia, Brazil, Canada, China, Egyp, -England, France, Greece, India, Israel, Italy, Japan, Kenya, Lebanon, Mexico, Nigeria, Portugal, Russian Federation, Senegal, South Korea, Spain, Sweden, European Union, World Health Organization, The Law Library of Congress, Global Legal Research Center, February 2015., str. 265; Keane J., Democracy and the Great Pestilence: understanding the mess we're in, 26 April 2020, http:// www.johnkeane.net/democracy-and-the-great-pestilence-understanding-the-mess-were-in/
} 
i mogućnost njihove zlouporabe budući da ustavi i međunarodni ugovori ne samo da vlastima daju mogućnost aktiviranja klauzula privremene suspenzije obveza u vrijeme krize, već im dozvoljavaju i upotrebu specijalnih ovlasti i donošenje mjera koje u pravilu predstavljaju ograničavanja slobode stroža nego u normalnim, redovnim okolnostima života.

Tako je primjerice niz država iskoristio izvanredne ovlasti za uspostavu mjera "izolacije" - usvojili smo engleski naziv lockdown koji inače ne postoji u vokabularu nomotehničkih pojmova države i prava, ali se je faktički materijalizirao u niz mjera zadržavanja, zatvaranja poslova koji nisu od vitalnog značaja, ograničenja javnog okupljanja i kretanja, a sve kako bi se stanovništvo prisililo da ostane unutar svojih domova s ciljem sprječavanja širenja zaraze. Takve mjere dakako imaju značajne posljedice po prava i slobode građana (primjerice slobodu kretanja ili slobodu udruživanja), a mogu se lako pretvoriti i u sredstvo kontrole političkog djelovanja te različitih institucija civilnog društva koje su od vitalnog značaja za ustavnu demokraciju i svekoliki razvoj društva. Prirodno je onda zapitati se kako konstitucionalizam funkcionira pod ekstremnim uvjetima? I posebno, na koje se je sve načine ustav izvanrednog stanja reflektirao na području sporta? ${ }^{3}$

\section{OPĆENITO O POJMU IZVANREDNOG STANJA U SUVREMENIM USTAVIMA (EMERGENCY CONSTITUTION)}

U najvećem broju suvremenih ustava postoje odredbe koje institucijama vlasti u izvanrednim situacijama - a to su situacije rata, invazije strane neprijateljske sile, oružanih pobuna, terorističkih napada, kao i prirodnih nepogoda, epidemija, te drugi oblici kriza ili katastrofa - dopuštaju poduzimanje mjera koje su nužne za očuvanje nacionalne sigurnosti, reda i poretka, zaštitu života i vlasništva građana, održavanje bitnih javnih službi, koncentraciju sredstava opskrbe i njihovo usmjeravanje tamo gdje su najpotrebnija, odnosno općenito one radnje koje osiguravaju povratak u stanje normalnosti. Takve odredbe o izvanrednim ovlastima sadržavaju i neki od najutjecajnijih ustava suvremenih ustavnih demokracija, među kojima su možda i

3 O konstitucionalizmu pod ekstremnim uvjetima pišu Albert R. \& Roznai Y. (ur.), Constitutionalism Under Extreme Conditions - Law, Emergency, Exception, Springer, 2020, https://www.springer. com/gp/book/9783030489991; vidi i Sahadžić M., Conference Report - International Symposium on "Constitutionalism under Extreme Conditions," University of Haifa, 2016, http://www. iconnectblog.com /2016/08 /conference-report-international-symposium-on-constitutionalism-under-extreme-conditionsuniversity-of-haifa/; vidi i tematski broj časopisa The International Journal of Human Rights, Volume 19, Issue 4, 2015 - National Security and Public Health: Human Rights in conflict 
Prof. dr. sc. Petar Bačić: Corona ante portas i "ustav izvanrednog stanja" u aktualnoj politici i pravu sporta Zbornik radova Pravnog fakulteta u Splitu, god. 58, 1/2021, str. 105-120

najpoznatije one u čl. 16. Ustava Republike Francuske $(1958)^{4}$ te čl. 115a Temeljnog zakona SR Njemačke (1949). ${ }^{5}$ Riječ je o odredbama koje tijelima vlasti omogućuju ograničenja ili ukidanja određenih ustavnih prava i sloboda, mehanizama institucionalnih kontrola i provjera, te koncentraciju odlučivanja u tijelima središnje izvršne vlasti. ${ }^{6}$ Takve su primjerice i odredbe iz čl. 17. Ustava Republike Hrvatske:

"(1) U doba ratnog stanja ili neposredne ugroženosti neovisnosti i jedinstvenosti države, te velikih prirodnih nepogoda pojedine slobode i prava zajamčena Ustavom mogu se ograničiti. O tome odlučuje Hrvatski sabor dvotrećinskom većinom svih zastupnika, a ako se Hrvatski sabor ne može sastati, na prijedlog Vlade i uz supotpis predsjednika Vlade, Predsjednik Republike. (2) Opseg ograničenja mora biti primjeren naravi pogibelji, a za posljedicu ne može imati nejednakost osoba s obzirom na rasu, boju kože, spol, jezik, vjeru, nacionalno ili socijalno podrijetlo. (3) Niti u slučaju neposredne opasnosti za opstanak države ne može se ograničiti primjena odredbi Ustava o pravu na život, zabrani mučenja, surovog ili ponižavajućeg postupanja ili kažnjavanja, o pravnoj određenosti kažnjivih djela i kazni, te o slobodi misli, savjesti i vjeroispovijedi". ${ }^{7}$

4 Ustav Republike Francuske, Constitution du 4 octobre 1958; (Version mise à jour en janvier 2015); Article 16 [State of Emergency] (1) When the institutions of the Republic, the independence of the nation, the integrity of its territory, or the fulfillment of its international commitments are under grave and immediate threat and when the proper functioning of the constitutional governmental authorities is interrupted, the President of the Republic takes the measures demanded by these circumstances after official consultation with the Prime Minister, the Presidents of the Assemblies, and the Constitutional Council. (2) He informs the nation of these measures by a message. (3) These measures must be prompted by a will to ensure within the shortest possible time that the constitutional governmental authorities have the means of fulfilling their duties. The Constitutional Council is consulted with regard to such measures. (4) Parliament meets ipso jure. (5) The National Assembly may not be dissolved during the exercise of emergency powers. (6) After thirty days of the exercise of such emergency powers, the matter may be referred to the Constitutional Council by the President of the National Assembly, the President of the Senate, sixty Members of the National Assembly or sixty Senators, so as to decide if the conditions laid down in paragraph one still apply. It makes its decision by public announcement as soon as possible. It carries out ipso jure such an examination and makes its decision in the same manner after sixty days of the exercise of emergency powers or at any moment thereafter.

5 Basic Law for the Federal Republic of Germany (1949, last amended on 28 March 2019), Article 115a . Čl. 115a [Declaration of a state of defence] (1) Any determination that the federal territory is under attack by armed force or imminently threatened with such an attack (state of defence) shall be made by the Bundestag with the consent of the Bundesrat. Such determination shall be made on application of the Federal Government and shall require a two-thirds majority of the votes cast, which shall include at least a majority of the Members of the Bundestag. (2) If the situation imperatively calls for immediate action and if insurmountable obstacles prevent the timely convening of the Bundestag or the Bundestag cannot muster a quorum, the Joint Committee shall make this determination by a two-thirds majority of the votes cast, which shall include at least a majority of its members. (3) The determination shall be promulgated by the Federal President in the Federal Law Gazette pursuant to Article 82. If this cannot be done in time, promulgation shall be effected in another manner; the determination shall be printed in the Federal Law Gazette as soon as circumstances permit. (4) If the federal territory is under attack by armed force, and if the competent federal authorities are not in a position at once to make the determination provided for in the first sentence of paragraph (1) of this Article, the determination shall be deemed to have been made and promulgated at the time the attack began. The Federal President shall announce that time as soon as circumstances permit. (5) If the determination of a state of defence has been promulgated, and if the federal territory is under attack by armed force, the Federal President, with the consent of the Bundestag, may issue declarations under international law regarding the existence of the state of defence. Under the conditions specified in paragraph (2) of this Article, the Joint Committee shall act in place of the Bundestag.

6 Bulmer E., Emergency Powers, International IDEA Constitution-Building Primer 18, International Institute for Democracy and Electoral Assistance, Stockholm, 2018., str. 6 et passim

7 Čl. 17. Ustava Republike Hrvatske, NN 85/2010 (pročišćeni tekst), 05/14. 
Bez obzira na to jesu li u pitanju mjere delegacije ovlasti šefu države ili nekom drugom ustavnom tijelu vlasti, izdavanje uredbi iz nužde, suspenzija zakonskih postupaka i prava, cenzura informacija, itd., njihova je svrha prije svega konzervativna. One se poduzimaju da bi se uklonile opasnosti po sistem, odnosno kako bi se realizirao povratak u prijašnje stanje. To nadalje podrazumijeva i da izvanredne ovlasti ne smiju tijelima izvršne vlasti poslužiti za definitivnu promjenu bilo kakvih elemenata ustavnopravnog sustava. Upravo je to uvjerenje jedno od temeljnih, možda čak i esencijalnih komponenti liberalne ustavnodemokratske vlade posvećene zaštiti prava, a kako to naglašavaju i J. Ferejohn i P. Pasquino. ${ }^{8}$ Takvo konzervativno korištenje izvanrednih ovlasti komplementarno je s različitim ustavnim mehanizmima njihove kontrole, odnosno s potrebom da se stanje izvanrednosti i službeno proglasi. Potreba deklaracije stanja izvanrednosti proizlazi iz različitih nesvakidašnjih situacija, poput oružanog napada na državu od strane unutrašnjih ili vanjskih elemenata, prirodnih nepogoda, građanskih nemira, epidemije (pandemije), velike ekonomske krize, ili pak generalnog štrajka koji paralizira zemlju. Međutim, premda su navedene pojave izuzetne, ne smije se zaboraviti da izvanredna stanja nisu baš ni nesvakidašnja pojava. To posebno vrijedi za diktatorske režime u kojima stanja izvanrednosti znaju trajati sve dok je režim na životu. U određenim situacijama deklarira se i ratno stanje (martial law) u kojem dominira vojska. Drugi pojmovi koji se referiraju na izvanredne situacije su izvanredno stanje (state of exception), stanje uzbune (state of alarm) i opsadno stanje (state of siege). U širokom rasponu, koji se pruža od klasičnog rimskog modela diktature do moderne ideje o ustavnim ovlastima izvanrednog stanja, postoje brojni modeli tog ustava izvanrednosti. ${ }^{9}$

U svakom slučaju, da bi se moglo na adekvatan način odgovoriti na izvanredne okolnosti, implementacija ustava izvanrednosti neminovno dovodi do ograničavanja ekonomskih, političkih i širih društvenih aktivnosti. Pritom se remeti uobičajeni mehanizam diobe vlasti, odlučivanje se u pravilu koncentrira u rukama izvršne vlasti, a mjere koje se poduzimaju iz nužde uvijek bi morale biti privremene i u onom opsegu koji odgovara potrebama situacije.

Istovremeno, postoji opasnost da vlast novonastalo stanje iskoristi za uvođenje arbitrarnih restrikcija građanskih prava i sloboda, za forsiranje ili pak za odgodu političkih izbora, ili za bilo koju drugu svrhu u kojoj vidi mogućnost stjecanja prednosti nad političkim suparnicima koju u normalnim okolnostima ne bi mogla tako lako ostvariti. Iz navedenog proizlazi i tendencija da se stanje izvanrednosti

\footnotetext{
8 Ferejohn J. \& Pasquino P., The law of the exception: A typology of emergency powers, I.CON, Volume 2, Number 2, 2004, str. 211.

9 Usp. Tushnet M., The political constitution of emergency powers: some conceptual issues, u Ramraj V.V. (ur.), Emergencies and the Limits of Legality, CUP, Cambridge, 2008., str. 145-155; Lazar N.C., A topography of emergency power, u Ramraj V.V. (ur.), Emergencies and the Limits of Legality, CUP, Cambridge, 2008., str. 156-171; vidi Camus G. \& Morange G., L'état de nécessité en démocratie, Librairie générale de droit et de jurisprudence, Paris, 1965., str. 428.; Ozbudun E. \& Turhan M., EmergencyPowers, European Commission for Democracy through Law, Science and technique of democracy No. 12, Strasbourg, 1995
} 
održi na snazi, iako je izvorni razlog zbog kojeg je ono uvedeno u međuvremenu prestao postojati.

Posebno je pak opasno shvaćanje da se iz takvog stanja ne može izroditi "ustavna diktatura". ${ }^{10}$ Neki od notornih primjera takvih država su Paragvaj za vrijeme diktature G. Stroessnera te Egipat za vrijeme H. Mubaraka. Izvanredne ovlasti su se u navedenim državama obnavljale i zapravo rutinski koristile s ciljem neutraliziranja političkih protivnika i gušenja miroljubivog otpora. Upravo to je jedan od najvažnijih razloga zbog kojih ustavne odredbe o izvanrednom stanju treba kreirati posebno pažljivo. Drugim riječima, a kako ističe E. Bulmer, pravi je izazov oblikovati ih na način koji će državi omogućiti da efikasno odgovori na stvarne izvanredne situacije, ali i da prevenira mogućnosti njihove autoritarne zloupotrebe. To jednostavno znači da "izvanredne ovlasti uvijek moraju biti podvrgnute odgovarajućim ustavnim garancijama i proceduralnim zaštitama". ${ }^{11}$

Kompleksna problematika konstitucionalizma pod ekstremnim uvjetima predstavlja permanentnu temu znanosti komparativnog ustavnog prava. Globalna uzbuna oko pandemije Covid-19 podsjetila je na stara te je otvorila i brojna nova pitanja o tome na koji se način javno pravo mijenja u razdobljima izvanrednog pritiska na ustav i ustavno pravo, ali i na druge pravne grane. ${ }^{12}$ Pritom teške udarce trpi i sportska sfera u kojoj se na poseban način manifestiraju efekti zdravstvene, ekonomske i financijske krize. Primjeri odgode Olimpijskih igara u Tokiju ili Europskog prvenstva u nogometu (EURO 2020) koje se je trebalo održati u dvanaest europskih zemalja samo su 'vrh ledenog brijega' u oceanu suspendiranih sportskih događaja koji su važni ne samo profesionalnim i amaterskim sportašima, već i brojnim sljedbenicima i ljubiteljima sporta. ${ }^{13}$

\section{O POSLJEDICAMA IZVANREDNOG STANJA NA SPORTSKOM POLJU}

Odgoda Olimpijskih igara do srpnja 2021. godine zbog pandemije koronavirusa posljednja je velika kriza u njihovoj dugoj povijesti. Prve Olimpijske igre u modernoj povijesti održane su 1896. godine, a od tada do danas bile su otkazane samo zbog velikih svjetskih ratova (to se odnosi na 1916., 1940. i 1944. godinu); teroristički napadi izvedeni za vrijeme igara 1972. u Munchenu i 1996. u Atlanti imali su tragične posljedice, ali ipak nisu doveli do njihovog otkazivanja. Dimenzije

10 Usp. Bačić A., Ustav i ustavna diktatura, Književni krug, Split, 1992.

11 Bulmer E., op. cit., str. 7

12 Albert R. \& Roznai Y. (ur.), Constitutionalism Under Extreme Conditions - Law, Emergency, Exception, Springer, 2020, https://www.springer.com/gp/book/9783030489991

13 Colucci M., Cottrell S., Sethna R. (ur.), Corona virus and its impact on football, A Sports Law and Policy Centre and Law In Sport Joint Survey, Brussels, London, Mumbai, 5 May 2020., https://www. sportslawandpolicycentre.com; Ahmed M., Di Stefano M, Nicolaou A., Can the sports industry survive the corona virus shutdown, Financial Times, April 5 2020, https://www.ft.com/content/fd7e58ec-743811ea-95fe-fcd274e920ca 
najmračnijih trenutaka u povijesti svjetskog sporta danas proširuje i aktualna pandemija koronavirusa kao kriza globalnih razmjera.

Pojam krize ima široki raspon definicija i interpretacija. Na jedan tipičan način kriza se može odrediti kao: "ekstraordinarni prekid standardnih aktivnosti koji ugrožava sigurnost, reputaciju i uspješnost organizacije ili pojedinca. U nekim slučajevima krize postoji mogućnost za društvo ili pojedince da ovladaju situacijom prije nego što nastupi ozbiljna šteta. Međutim, daleko su češći slučajevi da situacija izmakne kontroli prije nego što bude riješena. Način rješavanja problema naziva se kriznim upravljanjem (crisis management) $\mathrm{i}$ istodobno nam pokazuje sve razmjere pretrpljene štete. Iako se krize događaju u svakoj industriji, nijedna ne dobija toliko disproporcionalnu pažnju medija koliko ona u sportu". ${ }^{14}$

Države interveniraju u područje sporta i u redovnim okolnostima i u kriznim stanjima, a na to ih snažno potiču "javno mnijenje, kultura i nacionalni ponos". Sport je i danas "cirkus plebsa", baš kao što je bio i stoljećima ranije. Milijuni ljudi se u svoje slobodno vrijeme bave sportom i prate svoje omiljene sportove, natjecanja klubova i nacionalnih selekcija. Država pritom nastoji održati delikatnu ravnotežu između reguliranja zaštite sportaša i publike te očuvanja vrijednosti slobodnog izbora koje karakterizira razvijena liberalna društva. Sportske aktivnosti reguliraju se na različite načine: sport se podupire preko resornih mistarstava i njihovih politika koje se odnose na javno zdravlje, zakonski je uređeno oporezivanje sportaša i sportskih entiteta, posebno se reguliraju određene grane sporta, posebna regulativa donosi se i za sportove koji se povezuju sa sportskim kladionicama, a postoje i okolnosti u sportskom kontekstu koje iziskuju i primjenu kaznenog prava. ${ }^{15}$ Intervencija države u sport se u redovnim okolnostima života države i društva opravdava primjerice zaštitom sportaša od ozljeda. Na argument da se time mogu baviti sama sportska tijela odgovara se protuargumentima da država svojom intervencijom štiti društvene vrijednosti i omogućuje represiju kojoj je zadatak spriječiti druge u sličnom ponašanju. ${ }^{16}$ Država tako ostvaruje jednu od svojih temeljnih funkcija - očuvanje javnog reda i mira.

Potonji argument posebno dobija na težini u izvanrednim okolnostima, dakle u situacijama koje reguliraju odredbe ustava izvanrednosti. Pritom pod tim pojmom podrazumijevamo ne samo odredbe ustavne prirode, već i cjelokupni normativni rezervat koji obuhvaća norme različite pravne snage. Riječ je zapravo o skupini različitih ovlasti za različite oblike izvanrednih stanja, a među njima i izvanredna stanja javnog zdravlja. Takva regulativa, primjerice, često reflektira

14 Bernstein B., Crisis Management and Sports in the Age of Social Media: A Case Study Analysis of the Tiger Woods Scandal, Elon Journal of Undergraduate Research in Communications, Vol. 3 No. 2 , 2012, str. 1 .

15 Nelson A., When, Where and Why Does the State Intervene in Sport: A Contemporary Perspective, Sports Law e Journal, Vol. 1, No. 1, 2005, str. 2; http://classic.austlii.edu.au/au/journals/ SportsLaweJl/2005/2.html

16 Usp. Evans A.B. et al., Sport in the face of Covid19 pandemic: towards an agenda for research in sociology of sport, European Journal for Sport and Society, Vol. 17, No. 2, 2020, published online 14 May 2020, https://www.tandfonline.com/doi/full/10.1080/16138171.2020.1765100 
međunarodne ugovore koji nastaju pod okriljem univerzalnih organizacija poput Svjetske zdravstvene organizacije, a kojima se obuhvaćaju različite izvanredne situacije vezane uz javno zdravlje, biosigurnost, odnosno opasnosti kemijskog, biološkog, radiološkog i nuklearnog karaktera. ${ }^{17}$ Posljedica je navedene raznolikosti da se izvanredna stanja mogu deklarirati pod kišobranom različitih izvora prava. Situacije deklariranja raznovrsnih izvanrednosti (multiple emergencies) poznate su u komparativnom ustavnom pravu. ${ }^{18}$ Osim toga, recentni francuski primjer pokazao je i da se u slučaju hitne potrebe, bez obzira na postojeći ustavni i zakonski okvir izvanrednog stanja, s ciljem iznalaženja adekvatnog odgovora na neposrednu opasnost može stvoriti i novi režim izvanrednosti.

Naime, francuske političke vlasti su se nakon prvih dramatičnih rezultata širenja virusa potpuno usredotočile na rješavanje izazova pandemije. Iako se je zaraza proširila i među parlamentarnim zastupnicima, Assemblée Nationale je 23. ožujka uspjela usvojiti Zakon 2020-290 kojim se je legalizirao novi pojam 'izvanrednog stanja javnog zdravlja' (état d'urgence sanitaire). ${ }^{19}$ Tim su zakonom vladi omogućene izuzetne ovlasti u slučaju 'nastupanja zdravstvene katastrofe koja po svojoj težini i opsegu predstavlja ugrozu zdravlja stanovništva'. Dakle, u trenutku kada je zaraza koronavirusom počela izmicati kontroli, Ministarstvo zdravstva je predložilo mjere 'izvanrednog zdravstvenog stanja' koje su omogućile vladi da dekretima ograniči građanske slobode bez potvrde parlamenta. Mjere su raspravljene u oba doma parlamenta - Senatu i Nacionalnoj skupštini, a regulirale su više pitanja. Mjere s ciljem zaštite zdravlja odnosile su se na restrikcije putovanja, karantenu u trajanju od dva tjedna za osobe koje ulaze u zemlju, kao i na one koji su imali pozitivne rezultate testa na koronavirus, zatim na obavezno nošenje zaštitnih maski u javnom prijevozu, organiziranje kontroverznog info-sustava koji je trebao pratiti zaražene i njihove kontakte, itd. ${ }^{20}$ Sukladno podacima o slabljenju virusa i sve manjem broju ljudi na intenzivnoj skrbi država je trebala postepeno smanjivati tzv. lockdown, a nakon toga i ukinuti izvanrednu regulativu. ${ }^{21}$ Tako je u Francuskoj po prvi put proglašeno izvanredno stanje javnog zdravlja na kompletnom državnom teritoriju $i$ to na temelju hitnog regulativnog odgovora na pandemiju usvojenog u ubrzanoj zakonodavnoj proceduri.

17 Usp. Annas G.J., Bioterrorism, Public Health, and Civil Liberties, The New England Journal of Medicine, Vol. 346, No. 17, https://www.nejm.org/doi/full/10.1056/NEJM200204253461722

18 Opširnije vidi McLean H. \& Huf B., Emergency Powers, Public Health and Covid 19, Parliament of Victoria Research Papers, No. 2, August 2020, https://www.parliament.vic.gov.au/publications/ research-papers/download/36-research-papers/13962-emergency-powers-public-health-and-covid-19

19 Loi $\mathrm{n}^{\circ}$ 2020-290 du 23 mars 2020 d'urgence pour faire face à l'épidémie de covid-19, JORF n 0073 du 25 mars 2020, dostupno na: https://www.legifrance.gouv.fr/eli/ jo/2020/3/25/0073

20 Šire v. Platon S., From One State of Emergency to Another - Emergency Powers in France, VerfBlog, 2020/4/09, https://verfassungsblog.de/from-one-state-of-emergency-to-another-emergencypowers-in-france/

21 Gide's Covid-19 Booklet, Presentation of ordinances, 2 June 2020, Laws related to the state of emergency, emergency law no. 2020-290 of 23. march 2020 to deal with Covid-19 epidemic; Extension of the state of public health emergency and amendment of certain provisions relating to its regime. Creation of an information system to combat the COVID-19 epidemic, str. 4-9. 
Izvanredna stanja "guraju pravni poredak do njegovih krajnjih granica (Herkulovih stupova)", kako to primjećuju G. Martinico i M. Simoncini u radu u kojem analiziraju nastojanja da kod reguliranja nepredvidljivih scenarija prevlada vladavina prava. ${ }^{22}$ Upravo pojam izvanrednosti obuhvaća najteže takve situacije. Izvanredna stanja ističu se kao mogući okidač ustavnih promjena, ali i kao povod za svojevrsne pravne revolucije naglašavajući rizik od političke zlouporabe i tendenciju centralizacije vlasti u pravilu u rukama egzekutive odnosno nacionalnih vlada.

U praksi izvanrednosti otvaraju se kompleksna ustavna pitanja koja se najčešće odnose na probleme vlasti zadužene za koordinaciju i distribuciju izvanrednih mjera i akcija na razini centralne vlasti, njihovu problematičnu ustavnost, definiranje stanja izvanrednosti u ustavnim dokumentima, nadzor proglašavanja i posebno prolongiranja izvanrednog stanja od strane zakonodavne i sudbene vlasti, itd. Upravo je stoga jedan od ključnih ciljeva svakog pravnog poretka iznalaženje onih pravnih instrumenata koji mogu održati vladavinu prava i u izvanrednim okolnostima. U tom smislu i Venecijanska komisija zaključuje da de facto stanja izvanrednosti treba izbjegavati, odnosno da bi izvanredna stanja trebala biti i službeno proglašena. ${ }^{23}$

Što se pak konkretno sportskog polja tiče, globalni odgovor na pandemiju je bio gotovo potpuno isključivanje natjecateljskog sporta na svim razinama. Jedna od posljedica takvih mjera bio je i do tada neviđeni potres u sportskoj industriji. Već od prvih najava o razmjerima i mogućim posljedicama krize prouzročene globalnim širenjem koronavirusa postavljalo se je i pitanje može li sportska industrija preživjeti "coronavirus shutdown". Olimpijske igre u Tokiju i Europsko prvenstvo u nogometu samo su neki mega-primjeri katastrofalnih kriznih mjesta. Bostonski maraton koji okuplja više od 30.000 natjecatelja i gotovo milijun gledatelja otkazan je po prvi put u svojoj povijesti dugoj 124 godine, ${ }^{24}$ a jednak je ili sličan ishod i drugih masovnih svjetskih maratonskih utrka poput onih u Londonu, New Yorku, Barceloni ili Parizu. Kao posljedica otkazivanja ili odgode velike većine sportskih događaja prihodi ove velike industrije pali su na dramatično niske grane.

Nakon što je u ožujku donesena odluka o odgodi Olimpijskih igara za 2021. godinu, u svibnju je Međunarodni olimpijski odbor (MOO) procijenio da će snositi troškove do 800 milijuna američkih dolara zbog dijela odgovornosti za organizaciju. Sukladno prihvaćenom financijskom planu, Izvršni odbor MOO-a navedeni je iznos namijenio "za pokrivanje troškova organizacije Igara kroz proširene aktivnosti MOO-a (do 650 milijuna dolara) te kao paket pomoći olimpijskom pokretu, uključujući međunarodne sportske federacije, nacionalne olimpijske odbore i

22 Martinico G. \& Simoncini M., Emergency and Risk in Comparative Public Law, VerfBlog 2020/5/09, https://verfassungsblog.de/emergency-and-risk-in-comparative-public-law/

${ }^{23}$ Ibid.; European Commission for Democracy through Law (Venice Commission), Respect for Democracy, Human Rights and the Rule of Law During States of Emergency - Reflections, CDL-PI (2020)005, https://www.venice.coe.int/webforms/documents/?pdf=CDL-PI(2020)005rev-e; European Commission for Democracy through Law (Venice Commission), Compilation of Venice Commission Opinions and Reports on States of Emergency, CDL-PI (2020)003, https://rm.coe.int/16809e38a6

${ }_{24}$ Vidi https://sport.hrt.hr/619457/nakon-124-godine-prvi-put-otkazan-bostonski-maraton 
druge organizacije u članstvu MOO-a (do 150 milijuna dolara)". ${ }^{25}$ Ukupni troškovi organizacije Olimpijskih igara za Japan kao zemlju domaćina procjenjivali su se prije pandemije na 12 milijardi dolara, no recentne procjene govore da će se zbog odgode taj iznos povećati za dodatne 2,9 milijarde dolara, tako da će ukupni iznos troškova organizacije u konačnici dosegnuti oko 15 milijardi dolara. ${ }^{26}$ Financijski teret odgode bit će raspodijeljen između MOO-a, japanske Vlade te gradskih vlasti Tokija koji je kao grad domaćin investirao ogroman iznos s velikom vjerom u povrat uloženih sredstava. ${ }^{27}$

Sport općenito generira ogroman gospodarski utjecaj, a što je potpuno razvidno iz statističkih podataka. Procjenjuje se tako da globalno sportsko tržište vrijedi 756 milijardi američkih dolara godišnje, od čega se oko 420 milijardi dolara odnosi na Sjedinjene Američke Države, dok na Europu otpada trećina ukupnog iznosa. Što se pak Europske unije tiče, sportski sektor obuhvaća 2,12\% ukupnog iznosa bruto društvenog proizvoda, a zapošljava otprilike 5,76 milijuna ljudi ili 2,72\% od ukupno zaposlenih europskih građana, iz čega proizlazi da svaki trideset i sedmi zaposleni građanin Unije radi u sportskom sektoru. ${ }^{28}$ To istovremeno znači i da su ugroženi brojni tzv. mikro i mali poslovi povezani sa sportskim aktivnostima, poput teretana, fitness klubova, specijaliziranih marketinških agencija ili proizvođača različite sportske opreme. Posebno je delikatno pitanje tzv. malih sportova, ali i svih onih klubova koji se natječu u nižim ligama bez obzira na to o kojem je sportu riječ. Egzistencija ogromnog broja ljudi ugrožena je pandemijom i njenim svekolikim posljedicama, a sport pritom nije izuzetak. U potrazi za legitimnim mjerama borbe protiv pandemije i Republika Hrvatska je značajno reducirala sportske aktivnosti.

\section{REPUBLIKA HRVATSKA I POTRAGA ZA LEGITIMNIM MJERAMA BORBE PROTIV PANDEMIJE}

Prvi slučaj zaraze novim koronavirusom označen kao atipična upala pluća zabilježen je u gradu Wuhanu (NR Kina) 31. prosinca 2019. godine, a Svjetska zdravstvena organizacija (WHO) je zbog brzog širenja zaraze već 30. siječnja 2020. godine proglasila globalnu zdravstvenu krizu odnosno izvanredno stanje javnog zdravlja od međunarodnog značaja. ${ }^{29}$ Premda krajem siječnja još uvijek nije bilo oboljelih na području Republike Hrvatske, hrvatska je Vlada reagirala i usvojila određene mjere pripravnosti zbog epidemije koronavirusa, uključujući i prijedlog da se osnuje posebno središnje tijelo radi koordinacije svih službi u slučaju pojave

25 Usp. https://www.hoo.hr/hr/olimpizam/olimpijske-vijesti/609-korona-virus/6138-zbog-odgodeoi-tokio-2020-moo-predvida-troskove-od-800-milijuna-dolara

26 Usp. https://www.hoo.hr/hr/natjecanja/olimpijske-igre/olimpijske-igre/oi-tokio-2020/6357vraceni-olimpijski-krugovi-u-tokiju

27 Vidi Lewis L., The Quantum Mistery of Tokyo 's on-off Olympics, Financial Times, 13. 12. 2020. https://www.ft.com/content/0b641d03-b239-4037-b537-b733f091ed44

28 Usp. Krnjaic J., The Impact of the Covid Crisis on the Sport Industry, Marbella International University Centre, August 2020, https://miuc.org/impact-covid-crisis-sport-industry/

29 Usp. https://covid19.who.int/ 
Prof. dr. sc. Petar Bačić: Corona ante portas i "ustav izvanrednog stanja" u aktualnoj politici i pravu sporta Zbornik radova Pravnog fakulteta u Splitu, god. 58, 1/2021, str. 105-120

koronavirusa. ${ }^{30}$ Temeljem Zakona o sustavu civilne zaštite ${ }^{31}$ aktiviran je Stožer civilne zaštite Republike Hrvatske kao stručno i operativno tijelo za provođenje mjera i aktivnosti civilne zaštite u velikim nesrećama i katastrofama kojem je na čelu ministar unutarnjih poslova, a ministar zdravstva je Odlukom od 11. ožujka 2020. proglasio epidemiju Covid-19 temeljem ovlasti iz Zakona o zaštiti pučanstva od zaraznih bolesti. ${ }^{32}$ Tako je izvršna vlast i u Hrvatskoj, baš kao i u većini drugih država, od samog početka preuzela inicijativu u donošenju mjera s ciljem sprječavanja širenja zaraze.

Prve naputke i preporuke glede organizacije i održavanja sportskih natjecanja izdali su Središnji ured za sport i Hrvatski zavod za javno zdravstvo već početkom ožujka. Uslijed pogoršanja epidemiološke situacije ubrzo je izdana i preporuka o odgodi svih sportskih natjecanja u Republici Hrvatskoj do 1. travnja, uključujući i sva međunarodna natjecanja kojima je Hrvatska domaćin, a za provođenje te mjere zaduženi su nacionalni sportski savezi i krovna sportska udruženja. Odlukom Nacionalnog stožera civilne zaštite od 19. ožujka propisane su stroge protuepidemijske mjere i mjere tzv. socijalnog (zapravo - fizičkog, sic!) distanciranja, a to je podrazumijevalo i prekid svih sportskih natjecanja i organiziranih treninga, kao i obustavu rada teretana, sportskih centara, fitness i rekreacijskih centara. ${ }^{33}$

S ciljem ublažavanja posljedica restrikcija u sportskom sektoru, Hrvatski sabor je 17. travnja usvojio Zakon o dopunama Zakona o sportu. ${ }^{34}$ Novim zakonskim rješenjima predviđaju se različite mogućnosti intervencije u sustav natjecanja u slučaju nastupanja izvanrednih okolnosti, koje se definiraju kao "događaj ili određeno stanje koje se nije moglo predvidjeti i na koje se nije moglo utjecati, a koje ugrožava život i zdravlje građana, imovinu veće vrijednosti, znatno narušava okoliš, gospodarsku aktivnost ili uzrokuje znatnu gospodarsku štetu". ${ }^{35}$ Nadalje,

30 Vidi službene internet stranice Vlade Republike Hrvatske, https://vlada.gov.hr/vijesti/ministarstvozdravstva-osniva-se-nacionalni-krizni-stozer-zbog-koronavirusa/28676

31 Zakon o sustavu civilne zaštite, NN 82/15, 118/18, 31/20.

32 Zakon o zaštiti pučanstva od zaraznih bolesti, NN 79/07, 113/08, 43/09, 130717, 114/18, 47/20.

33 Kronologija zbivanja uz popis preporuka, preporuka i odluka usvojenih s ciljem sprječavanja širenja zaraze, a koje se odnose na sport i sportske aktivnosti, dostupna je na internet stranicama Hrvatskog olimpijskog odbora: https://www.hoo.hr/hr/olimpizam/olimpijske-vijesti/609-korona-virus. Popis odluka Stožera civilne zaštite RH s ciljem sprječavanja širenja zaraze dostupan je na: https://civilna-zastita.gov. hr/odluke-stozera-civilne-zastite-rh-za-sprecavanje-sirenja-zaraze-koronavirusom/2304

34 Zakon o sportu, Narodne novine 71/06, 150/08, 124/10, 124/11, 86/12, 94/13, 85/15, 19/16, 98/19, 47/2020.

35 Zakon o dopunama Zakona o sportu, Narodne novine 47/2020, čl. 1. - na temelju posebnih okolnosti "...nacionalni sportski savezi uz suglasnost tijela državne uprave nadležnog za šport mogu donijeti sustav natjecanja. Tijelo državne uprave nadležno za šport može dati suglasnost na sustav natjecanja na temelju mišljenja Hrvatskog olimpijskog odbora, Hrvatskog paraolimpijskog odbora odnosno Hrvatskog sportskog saveza gluhih. (4) U slučaju iz stavka 3. ovoga članka novi sustav natjecanja može biti u primjeni i ako od dana donošenja do početka primjene sustava natjecanja nije prošlo više od godine dana, a za što nacionalni sportski savez mora zatražiti suglasnost tijela državne uprave nadležnog za šport. (5) Odluku o novom sustavu natjecanja iz stavka 3. ovoga članka, kao i odluku o promjeni u sustavu natjecanja, kao i za završetak iste donosi tijelo upravljanja nacionalnog sportskog saveza sukladno statutu nacionalnog sportskog saveza, a iznimno ako se nadležno tijelo upravljanja nacionalnog sportskog saveza ne može sastati, zbog okolnosti iz stavka 3. ovoga članka, navedenu odluku donosi izvršno tijelo nacionalnog sportskog saveza.". 
predviđaju se i mjere pomoći u sportu, posebno u vidu potpore za očuvanje radnih mjesta u sustavu sporta. Na taj se je način otvorila mogućnost sportskim klubovima i drugim Zakonom ovlaštenim pravnim osobama da pod propisanim uvjetima zatraže naknadu plaće za svoje zaposlenike tj. pravo na potporu za očuvanje radnih mjesta. Pravo na potporu, o dodjeljivanju koje odluku donosi čelnik državnog tijela nadležnog za sport, ostvaruje se pod uvjetima da su radnici za koje se potpora traži zaposleni na neodređeno ili određeno radno vrijeme, ako im sredstva za istu namjenu nisu osigurana iz drugih javnih izvora, odnosno ako ispunjavaju uvjete za radno mjesto sukladno Zakonu o sportu i propisima o radu. Iznos i trajanje potpore te dodatni kriteriji prilagodbe razmjerima posebnih okolnosti i potrebama korisnika donose se u skladu s aktima Vlade RH. ${ }^{36}$

Naknadno stabiliziranje epidemiološke situacije omogućilo je i prvo ublažavanje restriktivnih mjera, pa je od 27. travnja dozvoljen povratak treninzima vrhunskim sportašima sukladno preporukama Hrvatskog zavoda za javno zdravstvo, ${ }^{37}$ a od 13. svibnja ponovno je omogućeno održavanje treninga, rad teretana, sportskih, fitness i rekreacijskih centara. Navedene i druge protuepidemijske mjere tijela izvršne vlasti su donosila pozivajući se na ovlasti iz dva zakona koja smo već naveli - Zakona o sustavu civilne zaštite i Zakona o zaštiti pučanstva od zaraznih bolesti. Taj je normativni okvir Hrvatski sabor naknadno izmijenio i dopunio, postupajući pritom u okviru čl. 16. Ustava RH:

"(1) Slobode i prava mogu se ograničiti samo zakonom da bi se zaštitila sloboda i prava drugih ljudi te pravni poredak, javni moral i zdravlje. (2) Svako ograničenje slobode ili prava mora biti razmjerno naravi potrebe za ograničenjem u svakom pojedinom slučaju". 38

Za razliku od čl. 17. Ustava koji regulira režim izvanrednog stanja i traži donošenje odluka dvotrećinskom većinom, ustavni čl. 16. omogućava zakonsko ograničavanje ljudskih prava i temeljnih sloboda u redovitim okolnostima i po uobičajenoj proceduri propisanoj za pojedine zakone. Izvanredno stanje u Hrvatskoj

36 Zakon o dopunama Zakona o sportu, Narodne novine 47/2020, čl. 2. dopunjava članak 74. Zakona na način da se iza stavka 3. dodaju se stavci 4. i 5. koji glase: »(4) U slučaju nastupanja posebnih okolnosti koje podrazumijevaju događaj ili određeno stanje koje se nije moglo predvidjeti i na koje se nije moglo utjecati, a koje ugrožava život i zdravlje građana, imovinu veće vrijednosti, znatno narušava okoliš, gospodarsku aktivnost ili uzrokuje znatnu gospodarsku štetu, čelnik tijela državne uprave nadležnog za šport može pravnim osobama iz ovoga Zakona dodijeliti potporu za očuvanje radnih mjesta ako ispunjavaju sljedeće uvjete: - ako su radnici za koje se potpora traži zaposleni na neodređeno ili određeno radno vrijeme, - ako im sredstva za istu namjenu nisu osigurana iz drugih javnih izvora, - ako ispunjavaju uvjete za radno mjesto sukladno ovom Zakonu i propisima o radu. (5) Čelnik tijela državne uprave nadležnog za šport donosi odluku o potpori za očuvanje radnih mjesta iz stavka 4. ovoga članka, kojom se utvrđuje iznos, trajanje potpore i dodatni kriteriji prilagođeni razmjerima posebnih okolnosti i potrebama korisnika, a sukladno aktima Vlade Republike Hrvatske.".

37 U pitanju je HZJZ-ov dokument naslovljen Preporuke za trening sportaša i sportašica I. I II. kategorije u pojedinačnim sportovima te seniorskim sportskim ekipama koje nastupaju u najvišem stupnju natjecanja: Održavanje treninga dopušta se sportašima i sportašicama I. i II. kategorije u pojedinačnim sportovima koji imaju izdano rješenje o kategorizaciji koju sukladno članku 6. Zakona o sportu izdaju Hrvatski olimpijski odbor, Hrvatski paraolimpijski odbor i Hrvatski sportski savez gluhih. Treninzi se dopuštaju i sportskim ekipama u muškoj i ženskoj seniorskoj konkurenciji koji nastupaju u najvišem stupnju natjecanja

38 Čl. 16. Ustava Republike Hrvatske, NN 85/2010 (pročišćeni tekst), 05/14. 
nije proglašeno, brojne odluke Stožera civilne zaštite pratili su ozbiljni prigovori o nelegalnosti zbog pozivanja na pogrešan zakonski temelj, ekcesivno korištenje ovlastima, itd., ${ }^{39}$ dok je Vlada prozvana za pokušaj njihove naknadne legalizacije. Odgovarajući upravo na takve i slične prigovore, Ustavni sud Republike Hrvatske svojim je Rješenjem od 14. rujna ove godine inter alia potvrdio da je tijelo izvršne vlasti koje je donosilo mjere za sprječavanje širenja virusa (Stožer civilne zaštite $\mathrm{RH}$ ) imalo ovlast za donošenje takvih mjera temeljem zakonskog okvira koji je uspostavio Hrvatski sabor (Zakon o sustavu civilne zaštite, Zakon o zaštiti pučanstva od zaraznih bolesti), a koji je pritom postupao u granicama svojih ovlasti propisanih Ustavom. ${ }^{40}$

Poboljšanje epidemiološke situacije tijekom ljetnih mjeseci omogućilo je nastavak sportskih natjecanja te ponovno otvaranje teretana i sportskih centara, a i ograničeni povratak gledatelja na sportska borilišta. Takve povoljne okolnosti bile su međutim kratkog vijeka, pa je Stožer civilne zaštite uslijed rapidnog porasta broja umrlih i zaraženih 27. studenog donio Odluku o nužnim epidemiološkim mjerama kojom su između ostalog ograničena okupljanja te su ponovno značajno reducirane sportske aktivnosti. Premda ovaj put sportska natjecanja najvišeg ranga nisu obustavljena, zabranjeni su treninzi i natjecanja na svim nižim razinama, dozvoljena natjecanja smiju se održavati isključivo bez prisustva gledatelja, a opet je obustavljen i rad teretana te fitness, sportskih i rekreacijskih centara. ${ }^{41}$ Upravo su

39 V. https://civilna-zastita.gov.hr/odluke-stozera-civilne-zastite-rh-za-sprecavanje-sirenja-zarazekoronavirusom

40 Vidi Rješenje Ustavnog suda u predmetima br. U-I-1372/2020, U-I-1999/2020, U-I-2075/2020, U-I-2233/2020, U-I-2161/2020, U-I-2234/2020, od 14. rujna 2020., Narodne novine 105/2020.

${ }^{41}$ Tekst Odluke Stožera civilne zaštite Republike Hrvatske o nužnim epidemiološkim mjerama kojima se ograničavaju okupljanja i uvode druge nužne epidemiološke mjere i preporuke radi sprječavanja prijenosa bolesti COVID-19 putem okupljanja od 27. studenog 2020. dostupan je na https://civilnazastita.gov.hr/UserDocsImages/CIVILNA\%20ZA\%C5\%A0TITA/PDF_ZA\%20WEB/Odluka\%20\%20 ograni\%C4\%8Davanja\%20okupljanja\%20i\%20druge\%20mjere.pdf ; Odlukom su propisane i stroge mjere fizičkog distanciranja koje nalažu izbjegavanje bliskog osobnog kontakta u razmaku od najmanje 2 metra u zatvorenom prostoru i 1,5 metar na otvorenom prostoru, a reducirane i pojedine sportske aktivnosti. Nužne epidemiološke mjere iz ove odluke, a koje se odnose na sportski sektor, su: - obustava rada teretana, fitness centara te sportskih i rekreacijskih centara; - zabrana svih treninga i natjecanja osim za klubove koji se natječu u 1. i 2. rangu natjecanja u seniorskoj konkurenciji i u 1. rangu natjecanja u juniorskoj konkurenciji na nacionalnoj razini u ekipnim sportovima te treninga i natjecanja vrhunskih sportaša (sportašice i sportaši I., II. i III. kategorije) u individualnim sportovima; - sportska natjecanja i treninzi koji su dopušteni mogu se održavati samo bez gledatelja i uz strogo pridržavanje svih propisanih epidemioloških mjera i posebnih preporuka i uputa Hrvatskog zavoda za javno zdravstvo, a organizatori su obvezni osigurati da se svi sportaši i nužno tehničko osoblje koje je prisutno pridržavaju propisanih epidemioloških mjera te da se sportski objekti iznimno koriste samo za potrebe dopuštenih treninga i natjecanja; - zabrana svih treninga i natjecanja osim za klubove koji se natječu u 1. i 2. rangu natjecanja u seniorskoj konkurenciji i u 1. rangu natjecanja u juniorskoj konkurenciji na nacionalnoj razini u ekipnim sportovima te treninga i natjecanja vrhunskih sportaša (sportašice i sportaši I., II. i III. kategorije) u individualnim sportovima; - sportska natjecanja i treninzi koji su dopušteni mogu se održavati samo bez gledatelja i uz strogo pridržavanje svih propisanih epidemioloških mjera i posebnih preporuka i uputa Hrvatskog zavoda za javno zdravstvo, a organizatori su obvezni osigurati da se svi sportaši i nužno tehničko osoblje koje je prisutno pridržavaju propisanih epidemioloških mjera te da se sportski objekti iznimno koriste samo za potrebe dopuštenih treninga i natjecanja. Usp. https://www.hoo.hr/hr/olimpizam/ olimpijske-vijesti/609-korona-virus/6353-najnovije-epidemioloske-mjere-stozera-civilne-zastite-rhreducirale-i-sportske-aktivnosti 
Prof. dr. sc. Petar Bačić: Corona ante portas i "ustav izvanrednog stanja" u aktualnoj politici i pravu sporta Zbornik radova Pravnog fakulteta u Splitu, god. 58, 1/2021, str. 105-120

potonje restrikcije izazvale snažne proteste i tužbe Ustavnom sudu o kojima će tek biti raspravljeno. ${ }^{42}$

\section{ZAKLJUČAK}

Bauk Covida-19 koji kruži svijetom s razlogom je prestravio suvremenu državu i društvo. Pandemija koja ne pravi razliku između razvijenog i nerazvijenog svijeta, bogatih i siromašnih država, zaostalih i razvijenih demokracija (premda se treba zapitati i što je to uopće danas u vrijeme trumpoida...), svojim intenzitetom i ritmom napredovanja, pustošenjem temeljnih ljudskih i društvenih vrijednosti, činjenicama o broju zaraženih i umrlih, još jednom opominje svijet na ogroman rizik hodanja na rubu civilizacijskog poduhvata. Ekstremna neoliberalna politika, koja je širom svijeta oslabila javne zdravstvene sustave, kompromitirala se je čak i u jednoj od najbogatijih država - Sjedinjenim Američkim Državama. Je li ova kriza doista dovela do toga da je nekada obožavano liberalno načelo Laissez. Faire - Laissez Passer u erodiranju socijalne države i njenih kapaciteta mutiralo u Laissez faire Laissez, Murrir? $?^{43}$

Aktualna komparativna praksa ustava izvanrednosti još je jednom pokazala žilavost ideje utjecajnog njemačkog pravnika Carla Schmitta o nepomirljivosti liberalne demokracije i izvanrednog stanja. Schmitt tvrdi da se izvanredna stanja ne mogu predvidjeti i ograničiti pravom (ustavom, zakonima) jer ona jednostavno iziskuju primjenu apsolutne vlasti. Ustavna demokracija je zbog toga uvijek na koljenima pred autoritarnom vladavinom. ${ }^{44}$ Potresen zbivanjima nakon terorističkih napada u Sjedinjenim Američkim Državama 9/11, Schmittove argumente osvježava suvremeni talijanski filozof Giorgio Agamben, iako ne dijeli njegove recepture. ${ }^{45}$ U svojoj knjizi 'State of Exception' objavljenoj 2005. godine Agamben tvrdi da je izvanredno stanje postalo "dominantna paradigma vlasti suvremene politike", a u kojoj se prema Schmittu nužno implicira operativnost izvanrednog stanja izvan granica zakona i pravnog poretka. Međutim, brojni suvremeni ustavni pravnici inzistiraju na stvaranju onoga što utjecajni američki konstitucionalist Bruce Ackerman naziva "ustavom izvanrednog stanja" (emergency constitution). U

42 Predsjednik Ustavnog suda Republike Hrvatske dr. sc. Miroslav Šeparović najavio je da će Ustavni sud do kraja siječnja 2021. godine odlučivati o mjerama pri čemu će "...Stožer morati objasniti na temelju kojih je zdravstenih i drugih razloga... donio Odluku o... zatvaranju teretana" i zašto je ono "bilo nužno, poštivajući načelo razmjernosti, da se spriječi širenje zaraze". Usp. https://dnevnik.hr/vijesti/ koronavirus/ustavni-sud-odlucuje-je-li-zatvaranje-teretana-bilo-opravdano-i-nuzno-nisu-nam-dalirazumno-objasnjenje-zasto-je-to-napravljeno---633308.html

43 Tako Assa J., Laissez-Faire, Laissez Mourir, Developing Economics - A Critical Perspective On Development Economics, March 31, 2020, https://developingeconomics.org/2020/03/31/laissez-fairelaissez-mourir/

44 Vidi Ryan B., Zones of exception (Carl Schmitt), In: Kierkegaard's Indirect Politics, Page Count: 89-133, https://brill.com/view/book/9789401210607/B9789401210607-s005.xml

45 Agamben G., State of Exception, University of Chicago Press, Chicago - London, 2005, str. 95; Vidi Kanwar V., Book review, International Journal of Constitutional Law, Vol. 4, Issue 3, July 2006, str. 567-575. 
pitanju je konstrukcija i primjena koherentnog skupa pravila s osnovnim zadatkom minimaliziranja rizika postupnog reduciranja i ugrožavanja građanskih sloboda u društvu kojemu sve više prijeti terorizam i općenito izvanredna stanja. ${ }^{46}$

Infiltracijom u sva područja života, pandemija kao izvanredno stanje javnog zdravlja dakako nije zaobišla ni sport. Stoviše, pritom je pogođen svaki element sportske sfere. Globalni odgovor na pandemiju bio je potpuno isključivanje natjecanja na svim razinama, a goruća pitanja odnose se ne samo na zdravlje sportaša, publike i svih onih koji su na različite načine uključeni u sportski sektor, već i na dramatični pad prihoda sportske industrije i mnogih koji o njoj ovise. Premda je postupno, dakako pod novim uvjetima i uz pridržavanje različitih epidemioloških mjera, došlo do nastavka većeg dijela sportskih natjecanja, sportski sektor i dalje je pod velikim pritiskom, a posebno je delikatno pitanje dugoročnog utjecaja virusa i slike sporta nakon pandemije. Nesporna je činjenica da je u potrazi za adekvatnim mjerama u borbi protiv pandemije dolazilo i dolazit će do različitih nesnalaženja i kontroverzi, pri čemu ni sport nije predstavljao izuzetak, no ovo izvanredno zdravstveno stanje još je jednom ukazalo na nezamjenjivu ulogu i značaj koordinirane akcije politike i prava na svim razinama.

46 Ackerman B., The Emergency Constitution, The Yale Law Journal, Vol. 113, No. 5, 2004, str. 1029-1091. 


\section{CORONA ANTE PORTAS AND "THE EMERGENCY CONSTITUTION" IN CURRENT POLITICS AND SPORTS LAW}

The sports sector is just one in a series of areas hard hit by the Covid-19 pandemic and measures taken by state authorities around the world against the spread of the deadly virus. The delays and cancellations of most sports competitions, starting with the Tokyo 2020 Olympics through a series of other events of international, national and local significance, have once again highlighted the irreplaceable role and importance of coordinated policy and law action at all levels. This situation has revealed to us again the importance of the emergency constitution in public law, but also other legal clauses (force majeure) that will be confronted by sports federations, competition organizers, clubs and the participants themselves in an effort to address serious economic and financial challenges. and the consequences regarding legal obligations arising from contracts in the field of sponsorship, sale and transmission of sporting events, etc. In this text the author points to the existence of the emergency state constitution, its forms and examples in comparative constitutional law, as well as the nature of events monitored the emergence and operation of institutions in an attempt to protect society. One of the fundamental questions is whether the Republic of Croatia, using a de jure or de facto state of emergency, helped or hindered sports.

Key words: emergency state constitution, reasons for declaring a state of emergency, sport, comparative constitutional law, Republic of Croatia Public Law 